\title{
PENINGKATAN MINAT BACA DAN KEMAMPUAN BERBAHASA INGGRIS ANAK DI RUMAH BACA BANDUNG
}

\author{
Mustangin \\ Pendidikan Luar Sekolah, Sekolah Pascasarjana, Universitas Pendidikan Indonesia \\ e-mail: mustangin1992@gmail.com
}

\begin{abstract}
Abstrak
Penelitian ini bertujuan untuk mengidentifikasi aktivitas yang dikembangkan oleh rumah baca di Rita Home Library dalam menumbuhkan minat baca dalam rangka pembentukan karakter anak. Desain penelitian yang digunakan pada penelitian ini adalah studi kasus dengan jenis penelitian kualitatif, dengan melakukan wawancara mendalam dan mengkaji dokumen yang terkait. Temuan penelitian menunjukkan bahwa di Rita Home Library berpusat pada peningkatan fokus bahasa inggris sehingga buku yang disajikan lebih banyak buku bahasa inggris, selain itu rumah baca di Rita Home Library menggabungkan antara perpustakaan rumah dan Pendidikan Nonformal yang sifatnya sukarela yaitu pembelajaran bahasa inggris di hari jumat dan minggu. Sehingga hal tersebut yang banyak menarik anak-anak untuk membaca di Rita Home Library. Dan akhirnya, model yang dilakukan pada rumah baca di Rita Home Library dapat menjadi acuan dalam mengembangkan model rumah baca untuk dapat menarik anak untuk berkunjung dan senang membaca.
\end{abstract}

Keyword: Kemampuan Bahasa Inggris, Minat Baca, Pendidikan Nonformal, Rumah Baca

\begin{abstract}
This study aims to identify the activities developed by home libraries at Rita Home Library in growing interest in reading in order to form the character of children. The research design used in this research is case study with qualitative research type, by conducting in-depth interviews and reviewing the related documents. The research findings show that the Rita Home Library focuses on improving the focus of English so that the book is presented with more books of English, in addition to the home read in Rita Home Library incorporates between home libraries and Non-formal Education which is voluntary namely learning English in Friday and Sunday. So that is what attracts many children to read in Rita Home Library. So that is what attracts many children to read in Rita Home Library. And finally, the model that is done at home read in Rita Home Library can be za reference in developing a model of home reading to be able to attract children to visit and enjoy reading.
\end{abstract}

Keywords : English Skill, Reading Interests, Nonformal Education, Home Library. 


\section{PENDAHULUAN}

Pendidikan merupakan pilar pembangunan bangsa yang artinya dengan adanya pendidikan tercapainya sumber daya manusia yang unggul sehingga akan menjadi aktor utama dalam pembangunan yang lebih baik lagi. Oleh karena itu pendidikan menjadi fokus utama dalam proses pembangunan. Salah satu hal yang dilakukan dalam kegiatan pendidikan adalah tentang penguasaan kemampuan membaca.

Penguasaan kemampuan membaca telah digalakkan diantaranya dengan perbaikan perpustakaan disetiap sekolahsekolah. Selain itu hal lain yang dilakukan untuk meningkatkan kemampuan membaca anak juga disediakan Mobil Pintar selain itu dibangunlah Taman Bacaan Masyarakat disetiap daerah yang dilakukan oleh pemerintah daerah maupun pihak swasta yang peduli terhadap pendidikan.

Taman bacaan masyarakat yang ada saat ini terdapat dalam berbagai bentuk diantaranya adalah Rumah Baca, Pondok Baca, Perahu Baca, Warung Baca. Keberagaman variasi mengenai taman baca masyarakat tetap sebagai salah satu tempat yang memiliki tujuan sebagai penyedia layanan perpustakaan bagi anak-anak dan masyarakat luas. Selain itu menurut Damayani, Silvana, Saepudin, dan Budiono (2017) taman bacaan masyarakat ini dapat memperluas wawasan masyarakat penggunanya dan sebagai media belajar sepanjang hayat.

Kehadiran Taman Baca atau Rumah Baca sebagai salah satu faktor pendorong minat baca bagi masyarakat khususnya bagi anak-anak. Hal ini disebabkan karena minat membaca di masyarakat yang masih rendah, sebagaimana yang disebutkan oleh Dani (2012) bahwa permasalahan membaca menjadi salah satu aspek perhatian pemerintah Indonesia sejak lama. Hal ini bukanlah tanpa alasan karena laporan Bank Dunia No.16369-IND dan studi IEA (International Association for the Evolution Achievement) di Asia Timur menyatakan bahwa tingkat terendah membaca anak-anak dipegang oleh Indonesia dengan skor 51,7 di bawah Filipina 52,6; Singapura 74,0; dan Hongkong 75,5. Kehadiran rumah baca diharapkan akan menumbuhkan minat JIPP, Volume 2 Nomor 2 Juli 2018 membaca bagi anak-anak, seperti yang diungkapkan oleh Saepudin, Sukaesih, dan Rusmana (2017) pembangunan taman bacaan masyarakat merupakan suatu bentuk keterlibatan seluruh unsur dalam membangun minat membaca masyarakat. Dengan adanya minat baca yang tinggi di masyarakat akan menjadikn masyarakat memiliki wawasan yang luas.

Salah satu rumah baca yang memberikan layanan perpustakaan kepada anak-anak adalah Rumah Baca di Rita Home Library yang ada di kota bandung. Fokus utama lembaga ini adalah menyediakan buku bacaan kepada anak-anak sekitar bandung.

Rumah Baca Rita Home Library di Bandung ini sendiri dipilih sebagai tempat penelitian karena memiiki ciri khas. Rumah baca ini didirikan sebagai inisiatif individu atau perorangan selain itu Rumah Baca ini tidak hanya sebagai perpustakaan saja namun juga dijadikan tempat pembelajaran nonformal dan yang menarik rumah baca ini lebih banyak menyediakan bacaan berbahasa inggris dan juga kegiatan pembelajaran untuk melatih anak-anak untuk terampil berbahasa inggris.

Penelitian ini sebelumnya pernah dikirim sebagai makalah dalam Seminar Nasional di Program Studi Pendidikan Pancasila dan Kewarganegaraan, Universitas Muhammadiyah Ponorogo dengan judul Aktivitas Rumah Baca Dalam Meningkatkan Minat Baca Untuk Pembentukan Karakter Anak dan telah dikaji lebih lanjut dan disempurnakan dengan judul baru yaitu Peningkatan Minat Baca Dan Kemampuan Berbahasa Inggris Anak Di Rumah Baca di Bandung. Dengan adanya penelitian ini diharapkan dapat menjadi kajian lebih lanjut untuk mengembangkan kegiatan yang ada di Taman Bacaan Masyarakat sehingga akan banyak anak-anak yang memiliki minat baca yang tinggi.

\section{METODE}

Metode penelitian yang digunakan pada penelitian ini adalah metode deskriptif kualitatif dengan pengertian metode prosedur penelitian yang menghasilkan data deskriptif berupa kata-kata tertulis atau lisan dari orangorang dan perilaku yang dapat diamati, didukung dengan studi literatur. Penelitian ini dilakukan di Rita Home Library Bandung, 134 
merupakan sebuah rumah baca yang memberikan layanan taman bacaan untuk anak-anak di Kota Bandung.

Sumber data dalam penelitian ini dibedakan atas sumber data primer dan sumber data sekunder. Sumber data primer didapat melalui wawancara yang mendalam kepada para informan yang bertujuan untuk untuk mendapatkan data primer. Wawancara dilakukan dengan beberapa informan, diantaranya adalah 1). Pemilik Rita Home Library; 2). Relawan yang ikut terlibat dalam kegiatan Pembelajaran di Rita Home Library; 3). Peserta didik yang mengikuti kegiatan pembelajaran.

Selain itu untuk mendapatkan data yang lebih akuran maka peneliti melakukan observasi berperan serta, artinya peneliti ikut terlibat dalam aktivitas yang terjadi di Rita Home Library Bandung.

Sumber data sekunder dilakukan dengan mengkaji berbagai informasi yang ada, berasal dari tulisan-tulisan yang mengangkat tentang Rita Home Library yang tersebar di berbagai media. Hal tersebut sebagai data pendukung yang diperlukan dalam penelitian ini. Dokumen-dokumen terkait dengan aktifitas Rita Home Library dikaji untuk kemudian dijadikan pelengkap data untuk penelitian ini.

\section{HASIL DAN PEMBAHASAN}

\section{Hasil Penelitian}

Aktivitas rumah baca di Rita Home Library sama halnya dengan rumah baca lainnya yaitu sebagai perpustakaan umum yang menyediakan sumber bacaan bagi anakanak di sekitar daerah bandung. Rita Home Library dengan koleksi bukunya dimanfaatkan oleh masyarakat khususnya anak-anak yang membutuhkan tambahan informasi dari bahan bacaan yang berguna untuk tambahan pengetahuan mereka.

Adapun hal yang berbeda dari Rita Home Library ini adalah mengenai koleksi buku bacaan yang disediakan oleh Rumah Baca ini. Pada Rumah Baca ini koleksi buku bacaannya lebih banyak adalah buku yang berbahasa inggris. Sebagaimana disebutkan kurang lebih 40.000 lebih buku tersebut terdiri dari beragam variasi jenis buku yang ada. Diantaranya buku cerita anak, novel, fiksi ilmiah maupun dokumenter yang JIPP, Volume 2 Nomor 2 Juli 2018 dibukukan. Rita Home Library memang tidak hanya menyediakan buku-buku bacaan yang berat seperti buku bacaan untuk orang dewasa, namun juga buku-buku ringan yang bisa menarik minat anak-anak untuk membaca. Cukup banyak koleksi buku cerita bergambar di sana yang selalu menjadi rujukan anak-anak.Buku tersebut di daat oleh Ibu Rita dari koleksi pribadi serta buku didapat dari donasi sewaktu masih bekerja sebagai pustakawan di Bandung International School.

Alasan kenapa buku yang dikoleksi oleh Rita Home Library kebanyakan merupakan buku-buku berbahasa inggris adalah karena Ibu Rita sebagai pemilik Rita Hime Library merupakan pensiunan dari Bandung International School yang lebih banyak dihadapkan dengaan buku-buku berbahasa inggris. Selain itu kepedulian terhadap anak-anak indonesia yang selalu minder kalau bertemu dengan orang asing sehingga mereka selalu takut salah dan malu berbicara dengan Bahasa Inggris.

Kehadiran Rita Home Library sebagai bentuk kepedulian Ibu Rita dalam rangka meningkatkan minat baca anak. Pengembangan Rumah Baca Rita Home Library ini bertujuan untuk memberikan kegiatan positif bagi anak-anak ini untuk membangun karakter mereka dan merangsang mereka untuk gemar membaca sebagai sumber pengetahuan. Kepedulian ini kemudian memunculkan ide pembangunan perpustakaan rumah yang dibuka untuk melayani tempat baca bagi anak-anak di sekitar rumah baca tersebut.

Selain itu aktivitas lain yang dilakukan di Rita Home Library ini adalah kegiatan pembelajaran berupa Kursus Bahasa Inggris. Hal yang menarik dari kegiatan pembelajaran bahasa inggris ini dilakukan kepada anak-anak yang ada disekitar kawasan Rita Home Library. Layanan pembelajaran bahasa inggris ini dilakukan secara gratis kepada anak-anak kurang mampu yang ada disekitar Rita Home Library. Sehingga hal tersebut dapat dimanfaatkan bagi anak-anak yang kurang mampu untuk mendapat kesempatan belajar bahasa inggris sekaligus dapat memanfaatkan Rita Home Library sebagai pusat kegiatan membaca untuk menambah pengalaman membaca anak-anak yang dari ekonomi kurang mampu. 
Peserta pembelajaran kursus di Rita Home Library saat ini lebih dari 150 anak, yang artinya ada lebih banyak anak yang dapat dilayani di Rita Home Library. Sehingga hal tersebut juga menandakan lebih banyak anak-anak yang memanfaatkan Rita Home Library sebagai pusat baca bagi anakanak. Hal tersebut dikarenakan anak-anak yang datang ke Rita Home Library bukan hanya belajar berbahasa inggris namun mereka juga datang untuk membaca bukubuku yang telah disediakan di Rita Home Library.

Anak-anak kurang mampu yang menjadi sasaran didik di Rita Home Library merupakan anak-anak yang berasal dari golongan kelas menengah kebawah. Kebanyakan anak-anak tersebut berasal dari orang tua yang bekerja sebagai kuli bangunan, pembantu rumah tangga, tukang gali pasir, buruh cuci. Sehingga untuk membeli buku menjadi hal yang tidak mungkin. Terlebih buku-buku yang berbahasa inggris. Bagi mereka buku merupakan barang yang mewah sehingga hal tersebut sulit bagi mereka untuk mendapatkannya. Kondisi seperti inilah yang menjadikan minat belajar anak-anak menjadi rendah. Sehingga keberadaan Rita Home Library dapat dijadikan sarana bagai mereka mendapatkan bahan bacaan yang gratis.

Pembelajaran bahasa inggris yang dilakukan oleh Rita Home Library juga dilaksanakan tidak hanya di rumahnya. Ibu Rita juga menyelenggarakan kursus bahasa inggris gratis yang dilakukan di Taman Film Bandung yang dilaksanakan secara rutin di Hari Jumat siang. Sasaran didik yang ada pada pembelajaran ini adalah anak-anak yang bertempat tinggal di sekitar kawasan Taman Film Bandung. Aktifitas yang dilakukan untuk pembelajaran di Taman Film Bandung ini tidak sama dengan yang dilakukan di rumah yang anak-anak dapat memanfaatkan buku bacaan secara langsung di perpustakaan, namun sumber belajar yang diambil untuk kegiatan belajar berasal dari perpustakaan di Rita Home Library.

Metode pembelajaran yang dilakukan oleh Ibu Rita dilakukan melalui cerita-cerita menarik yang didalam buku cerita berbahasa inggris. Anak-anak diajak untuk memilih sendiri buku serta topik pada buku cerita. Kemudian anak-anak diajak untuk membaca buku secara lebih teliti untuk kemudian anakJIPP, Volume 2 Nomor 2 Juli 2018 anak kemudian diminta untuk menyampaikan cerita apa yang telah dibacanya dengan bahasa inggris. Dengan cara itu anak-anak akan lebih menikmati kegiatan membaca.

Untuk para pemula yang belum lancar berbahasa inggris, ibu rita membacakan cerita yang diambil dari buku yang ada di perpustakaan tersebut. Karena cerita anak maka, anak tertarik untuk mendengarkan cerita tersebut. Cerita yang dibacakan tidak dibacakan sampai selesai namun anak-anak diminta untuk membaca sendiri, jika mereka tidak memahami arti bahasa inggris tersebut anak-anak dapat memanfaatkan kamus yang telah disediakan.

Dengan adanya pembelajaran bahasa inggris yang dijalankan di Rita Home Library ternyata menarik minat baca anakan-anak. Saat ini hampir setiap hari anak-anak datang ke Rita Home Library hanya untuk membaca buku. Mereka sudah tahu di mana kamus bahasa Inggris dan mereka bisa berlama-lama membaca sebelum berangkat atau selepas pulang sekolah. Aktivitas di Rita Home Library ini telah menjadi suatu sarana untuk dapat mempromosikan gerakan gemar membaca anak sehingga anak mendapat informasi yang lebih banyak dari kegiatan membaca tersebut.

\section{Pembahasan}

Rita Home Library sebagai Wadah Mengembangkan Minat Baca

Rumah baca merupakan layanan pendidikan yang berfokus pada penyediaan perpustakaan kepada masyarakat sebagai upaya mendukung masyarakat untuk gemar membaca. Rumah baca merupakan sebagai salah satu bentuk dari Taman Bacaan Masyarakat. dalam Buku Petunjuk Teknis Pengajuan, Penyaluran dan Pengelolaan Bantuan Taman Bacaan Masyarakat Rintisan tahun 2013 yang dikeluarkan oleh Direktorat Pembinaan Pendidikan Masyarakat bahwa adanya Taman Bacaan Masyarakat sebagai sarana pendidikan bertujuan untuk menumbuhkembangkan minat atau kegemaran membaca guna mewujudkan masyarakat pembelajar sepanjang hayat. Selain Itu menurut Indriyani, Raharjo, dan Ilyas (2017) bahwa Rumah Baca atau Taman Baca hadir sebagai tempat baca dengan suasana yang sederhana dan terbuka bagi siapa saja yang ingin memanfaatkannya. 
Dengan kata lain Rumah Baca merupakan sarana bagi masyarakat untuk mendapatkan akses memperoleh informasi.

Selain hal tersebut diatas menurut Jene, Yuniwati dan Rohmiyati (2013) Rumah Baca (Taman Baca Masyarakat) merupakan bagian dari kebutuhan masyarakat yang semakin berkembang. Terbentuknya Rumah Baca dimaksudkan untuk mendukung gerakan pemberantasan buta aksara, membantu mempercepat tumbuhnya aksarawan baru sekaligus memelihara dan meningkatkan kemampuan baca tulis masyarakat.

Kehadiran rumah baca di masyarakat sangat membantu dalam membantu masyarakat mendapatkan layanan bahan bacaan sebagai salah satu sumber informasi. Adanya rumah baca sekaligus sebagai pusat informasi di masyarakat yang sangat dibutuhkan untuk peningkatan pengetahuan masyarakat.

Keberadaan rumah baca di masyarakat menjadi sangat penting di masyarakat hal tersebut kaitannya dengan gerakan menumbuhkan minat membaca bagi masyarakat. Alasan tersebut telah diungkapkan oleh Khoiruddin, Taulabi, Imron (2016) bahwa Pengembangan budaya baca di masyarakat tidak hanya ditentukan oleh keinginan dan sikap terhadap bahan bacaan, tetapi juga ditentukan oleh ketersediaan dan kemudahan akses ke bahan bacaan. Hal yang sama juga didukung oleh regulasi yaitu pada Undang-undang Republik Indonesia Nomor 43 Tahun 2007 tentang perpusatakaan yang menyatakan bahwa Pemerintah, pemerintah daerah, dan masyarakat mendorong tumbuhnya rumah baca untuk menunjang pembudayaan kegemaran membaca.

Salah satu tujuan dibentuknya Rumah Baca adalah untuk meningkatkan minat baca masyarakat. sebelumnya mengenai pengertian minat menurut Kusrini dan Puspitasari (2006) yang dimaksud dengan Minat adalah dua pengertian yang berbeda tapi berkaitan. Minat adalah perpaduan keinginan dan kemauan yang dapat berkembang jika ada motivasi dan menjadikannya sebagai sebuah kebiasaan, terbentuknya suatu kebiasaan pada umumnya makan waktu lama dan dalam pembentukan itu minat dan motivasi mempunyai peranan menentukan. Jika minat dan motivasi tidak ada pada umumnya kebiasaan tidak tumbuh dan tidak berkembang. Selain itu mengenai JIPP, Volume 2 Nomor 2 Juli 2018 minat menurut Syah (dalam Harsono, Fuady dan Saddhono, 2012) minat (interest) berarti kecenderungan dan kegairahan yang tinggi atau keinginan yang besar terhadap sesuatu. Minat adalah keadaan emosi yang dasarnya ditujukan kepada sesuatu. Salah satu keadaan emosi adalah penilaian seseorang terhadap sesuatu yang dihadapi. Hasil penilaiannya dapat positif atau negatif, menarik atau tidak menarik, menyenangkan atau tidak menyenangkan.

Minat baca masyarakat merupakan suatu kedaan dimana masyarakat menjadi gemar membaca. Mengenai minat membaca Siswati (2010) mengungkapkan bahwa Minat terhadap membaca berarti disposisi yang mendorong individu untuk mencari kesempatan dan sumber-sumber untuk melakukan aktivitas membaca.

Selain itu pandangan terhadap Minat Membaca diungkapkan oleh Darmono (dalam Elfisa dan Yunaldi, 2012) minat baca merupakan kecendrungan jiwa yang mendorong seseorang berbuat sesuatu terhadap membaca. Minat baca ditunjukan dengan keinginan yang kuat untuk melakukan kegiatan membaca. Orang yang memiliki minat baca yang tinggi senantiasa mengisi waktu luangnya dengan membaca. Orang yang demikian denantiasa haus terhadap bahan bacaan. Minat membaca sangat berpengaruh terhadap keterampilan membaca.

Minat membaca ini dipengaruhi oleh beberapa hal diantaranya adalah kondisi dari tempat yang nyaman untuk membaca itu sendiri. Selain itu koleksi buku juga menjadi salah satu pendorong minat baca. Keberadaan rumah baca di tengahmasyarakat dapat juga sebagai pendorong minat baca anak karena sebagai tempat yang memberikan layanan perpustakaan bagi anak-anak. Koleksi buku yang ada di rumah baca dapat dimanfaatkan bagi anak-anak untuk mendapatkan tambahan bahan bacaan bagi anak-anak tersebut.

Peningkatan minat membaca memiliki peran penting untuk pendidikan. Hal tersebut didukung oleh pernyataan Basuki (2012) yang menyatakan bahwa kegiatan menbaca merupakan sesuatu yang penting den fundamental yang harus dikembangkan dalam rangka untuk meningkatkan kualitas pendidikan.

Oleh karena itu membaca ada kaitannya dengan pembentukan karakter 137 
bangsa, hal itu dilihat bahwa membaca ada kaitannya dengan peningkatan kualitas pendidikan. Sedangkan pembentukan karakter dapat dilaksanakan dengan bantuan pendidikan. Semakin berkualitas suatu pendidikan akan mempengaruhi pembentukan karakter yang berkualitas juga.

Kaitannya dengan pembentukan karakter, bahwa menurut Mumpuniarti (2012) bahwa Karakter adalah sebuah sifat-sifat yang mencirikan kepribadian seseorang yang membedakan dengan yang lain. Karakter itu mencirikan sesorang dalam merespon situasi dan kondisi sosial yang dihadapi. Berdasarkan pandangan tersebut yang dimaksud dengan karakter dalam individu adalah watak atau sifat dari individu yang menjadi ciri khas individu dalam bertindak di lingkungannya. Karakter juga sebagai pendorong seseorang untuk bersikap dalam kondisi tertentu. Pembentukan karakter dilakukan dengan cara mengarahkan, membimbing seseorang untuk memiliki watak atau sifat yang bisa dilakukan dengan kegiatan membaca. Dari buku itu menurut Kusrini dan Puspitasari (2006) peradaban manusia berkembang karena di dalam buku tersimpan rekaman- rekaman teori yang bisa melahirkan suatu teori baru, sehingga dalam perkembangan peradaban manusia, buku memang memiliki kekuatan yang dahsyat. Oleh karena itu dengan membaca buku akan dapat membentuk karakter individu yang mumpuni untuk membangun bangsa.

Rita Home Library sebagai salah satu layanan tempat baca bagi anak-anak yang membutuhkan buku bacaan, terutama bagi mereka yang kurang mampu yang tidak mungkin untuk membeli buku bacaan. Rumah Baca di Rita Home Library memberikan layanan yang sangat dibutuhkan bagi anakanak untuk dapat membaca buku berbahasa inggris. Sebagaiamana hal tersebut didukung oleh pernayataan Setyowati (2012) tentang layanan Rumah Baca sebagai bentuk Taman Bacaan Masyarakat bahwa Pengelola harus bisa menjamin memberikan layanan yang dibutuhkan oleh masyarakat. Selain itu perlu adanya peningkatan bahan bacaan, jam/ waktu layanan promosi serta berbagai kegiatan yang mendukung tumbuh kembangnya minat baca dan budaya baca. Rumah Baca yang baik dapat memberikan pelayanan yang memuaskan bagi pengguna. JIPP, Volume 2 Nomor 2 Juli 2018
Rumah Baca yang berhasil melayani masyarakat penggunanya antara lain terlihat dari berapa banyak orang yang memanfaatkan Rumah Baca setiap hari dan seberapa banyak menyediakan koleksi bacaan yang dibutuhkan penggunanya.

Adanya pelayanan yang baik di Rita Home Library telah meningkatkan minat baca yang lebih baik. Buku yang disediakan di Rita Home Library disesuaikan dengan minat anak-anak yaitu buku cerita yang menggambar selain itu buku bacaan yang ringan, yang artinya buku untuk anak-anak. Kaitannya dengan pelayanan yang memuaskan untuk menarik minat anak membaca seperti yang diungkapkan oleh Elfisa dan Yunaldi (2012) Menyediakan koleksi dan memberikan layanan yang baik dan sesuai kebutuhan anak, akan membuat anak-anak betah berada pada ruangan anak untuk membaca dan tujuan ruangan baca dalam menumbuhkan minat baca terhadap anak akan mudah tercapai secara sendirinya. Anak-anak harus menemukan kepuasan dalam membacanya, karena itu pustakawan tidak boleh mengabaikan selera anak-anak. Anak-anak membutuhkan bacaan-bacaan hiburan, informasi dan hal-hal yang menarik dari lingkungan nya.

Dilihat dari koleksi buku yang dimiliki oleh Rita Home Library benar-benar disesuaikan dengan kebutuhan anak. Buku berbahasa inggris menjadi salah satu yang dibutuhkan oleh anak-anak. Selain itu kebanyakan buku yang disediakan oleh Rita Home Library buku-buku cerita sehingga anak-anak akan menyukai buku-buku tersebut.

Terkait dengan bahan bacaan yang terdapat di Rita Home Library menyediakan berbagai macam buku seperti yang telah disebutkan Oleh Rahim (dalam Elfisa dan Yunaldi, 2012) bahwa agar ruang baca anak menjadi menarik bagi anak-anak sebaiknya disediakan koleksi berupa : a) Buku teks, yaitu buku fiksi atau karangan yang bersifat nonfiksi atau karangan yang bersifat nyata, b) buku sastra anak-anak, merupakan refleksi dari kehidupan, jadi buku sastra anak hendaknya dipilih sesuai dengan penglaman tentang kehidupan anak-anak, c) buku referensi, buku ini seperti kamus, atlas dan almanak, d) majalah anak, majalah ini banyak menyediakan informasi, sehingga anak-anak 138 
dapat membaca dan menemukan banyak informasi di dalam satu buku.

Rita Home Library selain dapat membaca buku, anak-anak yang datang di Rita Home Library juga mengikuti pembelajaran bahasa untuk meningkatkan kemampuan bahasa inggris anak. Aktivitas yang ada di Rumah Baca Rita Home Library dapat digambarkan sebagai berikut:

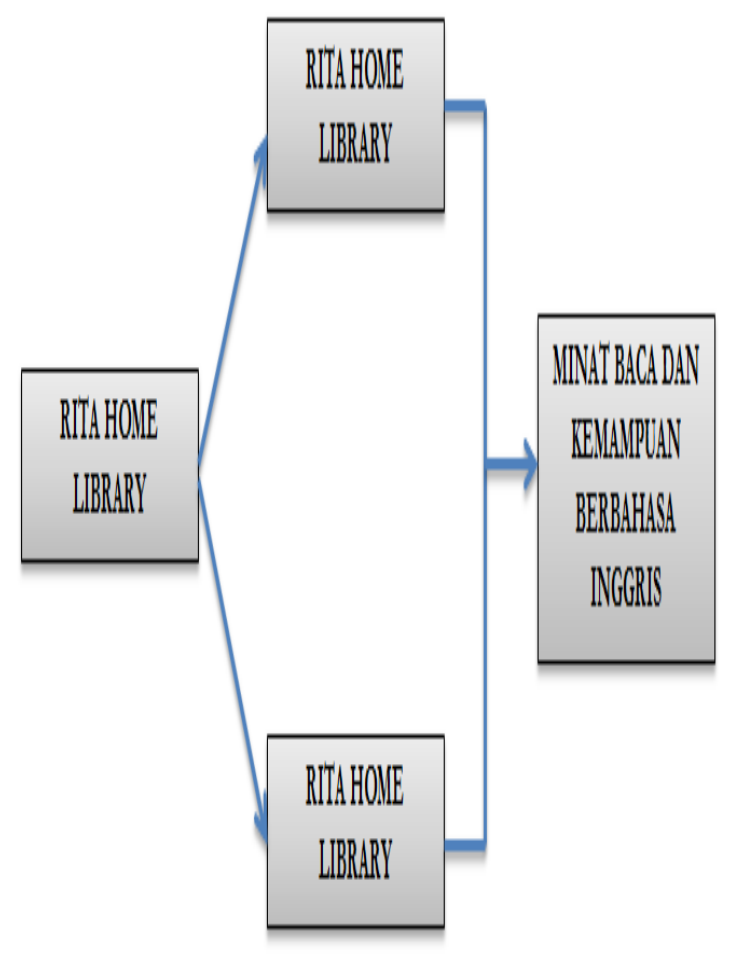

Gambar. 1 Bagan Aktifitas Rumah Baca di Rita Home Library

Dengan adanya pembelajaran bahasa inggris dikarenakan kebanyakan buku yang disediakan oleh Rita Home Library adalah buku berbahasa inggris. Dengan adanya pembelajaran tersebut, sehingga anak yang datang merasa puas dengan pelayanan yang diberikan di Rita Home Library. Rita Home Library sebagai rumah baca telah memberikan pelayanan yang maksimal. Pelayanan yang maksimal yang tidak hanya memberikan layanan perpustakaan namun adanya pembelajaran bahasa inggris sebagai salah satu aktivitas lain yang ada di Rita Home Library. Pelayanan yang maksimal di Rita Home Library Seperti halnya yang diungkapkan oleh Yusuf (2003) seharusnya pada ruangan baca anak terdapat berbagai JIPP, Volume 2 Nomor 2 Juli 2018 macam layanan yang diberikan kepada anak untuk menumbuhkan minat baca terhadap anak yaitu layanan membaca, bimbingan membaca, layanan rujukan anak, acara mendongeng dan pertunjukan film.

Kegiatan pembelajaran bahasa inggris yang dilakukan di Rita Home Library merupakan salah satu strategi kreatif yang dilakukan oleh Ibu Rita agara anak dapat memahami isi buku, dengan cara tersebut anak semakin tertarik dengan kegiatan membaca.

Kegiatan pembelajaran berupa kursus bahasa inggris sebagai salah satu penunjang aktivitas rumah baca, sehingga anak yang datang tidak hanya membaca buku namun mendapat pembelajaran yang nantinya mempermudah anak dalam memahami isi buku sehingga anak akan semakin tertarik untuk membaca buku. Hal tersebut sama dengan yang disampaikan oleh Irmawita (2014) bahwa Kegiatan pada Taman Bacaan Masyarakat bukan saja peminjaman bukubuku akan tetapi juga kegiatan membaca buku secara berkelompok yang kemudian dilanjutkan dengan diskusi dalam rangka tukar informasi dari kegiatan membaca yang dilakukan di lokasi taman bacaan masyarakat. Hal yang sama juga diungkapkan oleh Hayati dan Suryono (2015) Bahwa Nilai guna Taman Baca tidak sebatas penyedia layanan sirkulasi peminjaman buku saja, tetapi bisa lebih dari itu, Taman Baca sedikit demi sedikit mulai me-ngepakkan sayapnya untuk menjadi pendi-dik bagi masyarakat, penyedia ruang belajar, mendidik lewat buku, diskusi, forum mau-pun pusat kegiatan belajar masyarakat dalam wilayah tertentu.

Kegiatan pembelajaran bahasa inggris di Rumah Baca Rita Home Library dilakukan agar anak dapat membaca buku yang disediakan karena buku-buku yang disediakan memamng kebanyakan buku yang berbahasa inggris, sehingga mereka mampu memahami isi dari buku-buku tersebut.Selain itu ada tujuan lain yang hendak dicapai yaitu bertujuan untuk meningkatkan kepercayaan diri dari anak-anak untuk berbahasa inggris. Sehingga kebanyakan buku-buku yang disediakan merupakan buku berbahasa inggris. Hal tersebut erat kaitannya dengan pembentukan karakter anak. karakter yang dimunculkan adalah karakter percaya diri. Adanya Rita Home Library sebagai sarana 139 
untuk meningkatkan rasa percaya anak, melalui pelayanan perpustakaan buku bahasa inggris dan pembelajaran bahasa inggris. Layanan yang dilakukan di Rita Home Library kaitannya dengan pembentukan karakater didukung oleh pernyataan Istiningsih (2013) Karakter manusia dapat dikembangkan oleh pengaruh lingkungan termasuk melalui pengalaman dan belajar melalui ilmiah. Pengembangan karakter seseorang yang timbul dari kehidupan sosial yang semakin kompleks, yang bila dikaitkan dengan gambar ekologi dari proses pendidikan adalah hasil dari interaksi antara sifat anak dengan dampak lingkungan. Rita Home Library sebagai salah satu sarana mendapatkan pengalaman dan pembelajaran untuk pembentukan karakter anak melalui buku-buku yang dibaca oleh anak-anak ditambah dengan pembelajaran bahasa inggris yang diberikan.

\section{SIMPULAN}

Rumah Baca di Rita Home Library merupakan salah satu bentuk dari Taman Bacaan Masyarakat yang didirikan secara mandiri oleh perorangan yaitu Ibu Rita merupakan salah satu layanan pendidikan nonformal. pelayanan yang baik di Rita Home Library telah meningkatkan minat baca yang lebih baik. Buku yang disediakan di Rita Home Library disesuaikan dengan minat anak-anak yaitu buku cerita yang menggambar selain itu buku bacaan yang ringan, yang artinya buku untuk anak-anak. koleksi buku yang dimiliki oleh Rita Home Library benar-benar disesuaikan dengan kebutuhan anak. Buku berbahasa inggris menjadi salah satu yang dibutuhkan oleh anak-anak. Selain itu kebanyakan buku yang disediakan oleh Rita Home Library bukubuku cerita sehingga anak-anak akan menyukai buku-buku tersebut. Selain sebagai layanan perpustakaan Rita Home Library juga memberikan layanan Pembelajaran Bahasa Inggris yang kebanyakan peserta didiknya adalah anak-anak dari kalangan kurang mampu. Kegiatan pembelajaran bahasa inggris yang dilakukan di Rita Home Library merupakan salah satu strategi kreatif yang dilakukan oleh Ibu Rita agara anak dapat memahami isi buku, dengan cara tersebut anak semakin tertarik dengan kegiatan membaca. Dengan adanya pembelajaran JIPP, Volume 2 Nomor 2 Juli 2018 tersebut anak-anak semakin tertarik untuk berkunjung ke Rita Home Libarary, aktivitas itulah yang dapat menarik minat anak untuk dapat gemar membaca.

\section{DAFTAR RUJUKAN}

Basuki, R. 2012. Pembentukan Karakter Anak Bangsa Melalui Peningkatan Budaya Minat Baca. Dalam Chanafiah, Y dan Agustina, E. (ed). Seminar Nasional Membaca Karakter, Hal. 77-82, Bengkulu: FKIB Universitas Bengkulu

Damayani, N.A., Silvana, T., Saepudin, E., \& Budiono, A. 2017. Pengembangan Taman Bacaan Masyarakat Di Desa Sindangkerta Kecamatan Cipatujah Kabupaten Tasikmalaya. Dharmakarya: Jurnal Aplikasi Ipteks Untuk Masyarakat. Vol. 6 No. 1, 5761

Dani, D.E. 2012. Program Desa Buku Taman Kyai Langgeng Magelang Sebagai Solusi Menumbuhkan Budaya Baca Masyarakat. Jurnal Ilmiah Kajian Humoniora: Humanika. Vol. 15 Tahun IX. Januari-Juni, 2012

Direktorat Pembinaan Pendidikan Masyarakat. 2013. Buku Petunjuk Teknis Pengajuan, Penyaluran dan Pengelolaan Bantuan Taman Bacaan Masyarakat Rintisan. Jakarta: Direktorat Pembinaan Pendidikan Masyarakat, Ditjen PAUDNI, Kementerian Pendidikan dan Kebudayaan

Elfisa, M.K dan Yunaldi. 2012. Layanan Pustakawan Anak Terhadap Anak Di Perpustakaan Proklamator Bung Hatta Dalam Menumbuhkan Minat Baca Anak. Jurnal Ilmu Informasi Perpustakaan dan Kearsipan. Vol. 1 No. 1, September, 2012, 206-214

Harsono, A.S.R., Fuady, A \& Saddhono, K. 2012. Pengaruh Strategi Know Want To Learn (KWL) Dan Minat Membaca Terhadap Kemampuan Membaca Intensif Siswa Smp Negeri Di Temanggung. Jurnal Penelitian Bahasa, Sastra Indonesia dan Pengajarannya (BASASTRA), Vol. 1 No. 1, 53-64

Hayati, N \& Suryono, Y. (2015). Evaluasi Keberhasilan Program Taman Bacaan Masyarakat Dalam Meningkatkan Minat Baca 140 
Masyarakat Di Daerah Istimewa Yogyakarta. Jurnal Pendidikan dan Pemberdayaan Masyarakat, Vol. 2 No. 2, 175-191

Indriyani, I., Raharjo, T.J \& Ilyas. 2017. Pengelolaan Taman Bacaan Masyarakat Dalam Kemajuan Literasi Pada Pondok Maos Guyub Kendal. Journal of Nonformal Education. Vol. 3 No. 2, 132-139

Irmawita. 2014. Penataan Taman Bacaan Masyarakat (TBM) Sebagai Sarana Pembelajaran Warga Belajar Pendidikan Nonformal. Jurnal Ilmiah Ilmu Pendidikan.Vol. 16 No. 2, 72-81

Istiningsih. 2013. Contribution of Religion and Media Awareness in Building Character Appearance in the Family, Campus, Community, and in the Self (Study of Student Perceptions in Yogyakarta). Journal of Education and Practice. Vol. 4 No. 9, 71-79

Jene, O.C, Yuniwati \& Rohmiyati, Y. 2013. Peran Taman Bacaan Masyarakat Dalam Menumbuhkan Budaya Baca Anak Di Taman Bacaan Masyarakat "Mortir" BanyumanikSemarang. Jurnal Ilmu Perpustakaan. Vol. 2 No. 2, Agustus, 2013, 1-10

Khoiruddin, M.A., Taulabi, I \& Imron, A. 2016. Menumbuhkan Minat Baca Sejak Dini Di Taman Baca Masyarakat. Jurnal An-Nafs. V01 1 No. 2, 291-319
Kusrini, D.E \& Puspitasari, D. 2006. Penggunaan Analisis Regresi Logistik Untuk Menganalisis Perilaku Dan Faktor-Faktor Yang Mempengaruhi Minat Baca Pengunjung Badan Perpustakaan Propinsi Jawa Timur. Jurnal Matematika. Vol. 9 No. 1, April, 2006, 149-155

Mumpuniarti. 2012. Pembelajaran Nilai Keberagaman Dalam Pembentukan Karakter Siswa Sekolah Dasar Inklusi. Jurnal Pendidikan Karakter. Vol. 2 No. 3, Oktober, 2012, 248-257

Saepudin, E., Sukaesih \& Rusmana, A Peran Taman Bacaan Masyarakat (TBM) Bagi Anak-Anak Usia Dini. 2017. Jurnal Kajian Informasi \& Perpustakaan. Vol. 5 No. 1, 1-12

Setyowati, L. 2012. Pelaksanaan Fungsi Manajemen Taman Bacaan Masyarakat (TBM). J+Plus Unesa. Vol. 1 No. 1, Agustus, 2012, $1-5$

Siswati. 2010. Minat Membaca Pada Mahasiswa (Studi Deskriptif Pada Mahasiswa Fakultas Psikologi Undip Semester I). Jurnal Psikologi Undip. Vol. 8 No. 2. Oktober, 2010, 124-134

Yusuf, Taslimah. 2003. Manajemen Perpustakaan Umum, Jakarta: Universitas Terbuka

Undang-Undang Republik Indonesia Nomor 43 Tahun 2007 Tentang Perpustakaan 